\title{
Specific Resistance Hybrids of Hexaploid Synthetic Wheat (HSW) and Commercial Cultivars to Stripe Rust in Kazakhstan
}

\author{
Gulnur Almasovna Suleimanova ${ }^{1}$,Yerlan Bozanbaiulu Dutbayev ${ }^{1}$ \\ and Nadira Zhumahanovna Sultanova ${ }^{2}$
}

\begin{abstract}
${ }^{1}$ Kazakh National Agrarian University, Kazakhstan, 050010, Almaty, Abay avenue 8 ${ }^{2}$ Kazakh Research Institute for Plant Protection and Quarantine Kazakhstan,
\end{abstract} Almaty, Almaty obl. Rahat vil. Kazybek bi st. h, 1.

http://dx.doi.org/10.13005/bbra/2118

(Received: 11 March 2016; accepted: 01 May 2016)

\begin{abstract}
Studying of inheritance of resistance to stripe rust in 2015 in F1 generation of crosses in crosses of lines of synthetic wheat with commercial cultivars of winter have been conducted on adult plants and on seedlings. On natural background of spores of Puccinia striiformis West $\mathbf{7 9} \%$ hybrids showed high resistance on adult plants. On artificial background the evaluation of seedlings showed that $46 \%$ of lines showed resistance to this disease. As the result, adult plants and seedlings wheat hybrids have showed different resistance to stripe rust. The studying of correlation dependence between spikes productivity components in artificial and in natural background of spores of $P$. striiformis West. pointed that during first case on seedlings have been pointed previously moderate and high correlation between indexes of spikes productivity in comparative with case on adult plants with natural inoculations which showed low correlation.
\end{abstract}

Keywords: Specific Resistance, Synthetic Wheat, Breeding, Stripe Rust, Line, Seedlings, Adult Plant.

Grain production is an important strategic resource of Kazakhstan for the basic sector of agricultural production. The Republic produces wheat grain for the internal needs and is also for an export to the foreign countries. $W$ inter wheat is cultivated mainly in the southern and southeastern regions of the country in the area of $1.5-2 \mathrm{mln}$. hectars (he), including 140,5-170,4 thousand he. Kazakhstan, as one of the major grain producers in the world, at the level of wheat yields 15-20 tones per/he annually yield losses can be up to $0.35-0,95$ tonnes/he of grain ${ }^{1}$. One of the main reasons for this losses are widespread outbreaks of fungal diseases, including one of the most malicious a stripe rust (pathogen Puccinia striiformis West.).

\footnotetext{
* To whom all correspondence should be addressed.
}

In Central Asia, the disease Is rather serious in the in the southern and southeastern regions of Kazakhstan, Uzbekistan and the Kyrgyz Republic. Studying of stripe rust epidemiology in the mountainous area of Almaty oblast showed, yield losses from these diseases can be up to $16-31 \%{ }^{4}$. A disease ephyphitoties of stripe rust during the last 15-16 years occurred in 1999, 2002 and $2009^{2-3}$. In order to make a food more secure for world's population by 2030 , it is necessary to increase the yield potential of wheat pruductivity up to 30-40\%. For this purpose potential of wheat yield must be increased for every year up to 1.6-1.8\% including $1 \%$ for breeding and for genetic methods. Reaching the final goal would be possible in the case of utilizing of genetic resources of wheat wild varieties $^{4}$.

One is the most perspective methods for stable plant protection is seemed to be using wheat cultivars with non-specific mechanisms of resistance to disease. Scientists from International 
Maize and Wheat Improvement Centre (CIMMYT) had formulated the concept of the principle of nonspecific resistance slowing the progression of the disease - (slow rusting) ${ }^{5}$. This type of resistance to disease is also called as a partial resistance ${ }^{6}$. During the last years the concept of non-specific resistance have been widely used in cereal breeding programs to rust diseases ${ }^{6,7}$.

\section{METHODS}

Since 2014 the breeding and immunological studies of synthetic hexaploid wheat from Kyoto University, Japan, and from CIMMYT are conducting on the experimental fields of the Kazakh Research Institute of Farming and Plant growing ( KazNIIZiR ) according to generally accepted in plant pathology, plant breeding and plant growing methods ${ }^{8,12,13}$. Weather conditions in 2013-2014 and 2014-2015 agricultural years in the Almaty region have been the same with average long-term performance and had lead to mild disease occurrence.

In the autumn of 2013 from Turkey (CIMMYT ) were received and sown seeds of 49 samples of nursery of hexaploid synthetics hexaploid wheat (HSW) 13JAP-SYNT. Seed have been sown on October 18. Each line have been sowed in one row with length one meter at a depth of $5 \mathrm{~cm}$. The rate of 25-35 grains per row. During the growing season on the natural infectious background have been conducted phenological observations with aim to determine period of maturity and disease occurrence. During wheat heading have been done crossing between $10 \mathrm{HSW}$ lines and 5 commercial cultivars of winter wheat. In 2015, on the artificial infectious background of yellow rust spores in field conditions have been conducted studies of inheritance of traits in the F1 generation for resistance to yellow rust in crosses HSW with commercial cultivars of winter wheat. The evaluation of lines have been done twice time - during ear formation and wax ripeness by McIntosh scale ${ }^{9}$. This work have been carried out as a visual evaluation of disease manifestations in points .

Determination of resistance to yellow rust on wheat seedlings of HSW hybrids have been carried out during winter period in greenhouse of Kazakh National Agrarian University (KazNAU).
Seeds of hybrids have been sowed in pots in the greenhouse in two repeat. After 14 days of inoculation by spores of Puccinia striformis we have been done observation of diseases occurence by McIntosh scale ${ }^{9,14,15}$

\section{RESULTSAND DISCUSSION}

There are two types of specific plant resistance - one for adult plants and next one for seedlings ${ }^{14}$. The main researches in the direction of age resistance of wheat to diseases had been carried out in the USA ${ }^{10}$. Later researches established that that some resistance genes to leaf rust, was effective in Europe, USA, Canada, were not effective in other countries ${ }^{11}$.

In this side it is interesting to study the effectiveness of genes of HSW wheat nursery for age resistance to yellow rust, which population in Kazakhstan in connection to different climatic conditions and the races of pathogen. Synthetic diploids include inside genomes of various species of cereal grasses. These sources can greatly facilitate transferring of genetic material properties of wild species to wheat. Lines of wheat had been developed from crossing of tetraploid Triticum turgidum and diploid wild Aegilops Aegilops tauschi to improve the propertial potential of wheat . These hybrids have properties of resistance to abiotic (drought, high temperatures, salinity , lack of moisture ) and to biotic stresses (rusts spp.) ${ }^{5}$.

The study of inheritance of traits of resistance in field condition in the F1 generation in crosses of HSW with commercial cultivars of winter have shown that, standards cv. Azharly, Naz, Farabi, Zhetysu had been injured by yellow rust on moderate level. 14 lines of HSW had showed high resistance to disease: LANGDON/KU-20-8/ FARABI, LANGDON/KU-2075/AJARLY, LANGDON/KU-2075/FARABI, LANGDON/KU2092/FARABI, LANGDON/KU-2144/ STEKLOVIDNAYA, LANGDON/KU-2100/NAZ, LANGDON/AT 55/STEKLOVIDNAYA, LANGDON/ PI 508262/STEKLOVINDAYA, LANGDON/KU2097/ZHETISU, LANGDON/KU-2097/AJARLY, LANGDON/KU-2144/NAZ, LANGDON/IG 48042/ ZHETISU, LANGDON/IG 48042/FARABI, LANGDON/KU-2076/ZHETISU, 2 of them did not have any grain. Other lines had weight of 100 grain on same level like standard had - 0, 2 gramm. One 
line showed moderate resistance to stripe rust LANGDON/KU-2076/NAZ. Only two lines have been injured by disease on high level: LANGDON/ KU-20-8/ AJARLY è LANGDON/PI 508262/ ZHETISU. As the result, 79\% of adult hybrids of HSW of F1 generation showed resistance to stripe rust.

The evaluation of specific resistance of seedlings of hybrids of HSW and commercial winter wheat cultivars showed, that on artificial inflectional phones of P.striiformis cultivars Azharly and Farabi have been injured by diseases in strong level (susceptible). In this condition 7 lines of hybrids have showed resistance to the disease in earring stage (LANGDON / KU-2075 / FARABI, LANGDON / KU-2092 / FARABI , LANGDON / KU-2100 / NAZ, LANGDON / AT 55 / STEKLOVIDNAYA, LANGDON / PI 508262 / STEKLOVINDAYA, LANGDON / PI 508262 / ZHETISU, LANGDON / KU-2097 / AJARLY). The 4 lines have shown moderate susceptible to disease (LANGDON/KU-20-8/AJARLY,LANGDON/KU20-8 / FARABI, LANGDON / KU-2144 / NAZ) and 2 ones ( LANGDON / KU-2075 / AJARLY, LANGDON / KU-2097 / ZHETISU) were susceptible to disease. As the result, only $46 \%$ of

Table 1. Evaluation of specific resistance of seedlings of hybrids of HSW and commercial cultivars stripe rust (KazNAU, Kazakhstan, 2015)

\begin{tabular}{llccc}
\hline $\begin{array}{l}\text { S. } \\
\text { No. }\end{array}$ & Hybrids & $\begin{array}{c}\text { Weight of } \\
\text { leaf, gramm }\end{array}$ & $\begin{array}{c}\text { Length of } \\
\text { roots, cm }\end{array}$ & $\begin{array}{c}\text { Injuring of } \\
\text { hybrids by } \\
\text { disease, grate }\end{array}$ \\
\hline 1 & AJARLY & $3,2 \pm 0,2$ & $1355,8 \pm \pm 67,8$ & $\mathrm{~S}$ \\
2 & FARABI & $1,6 \pm 0,1$ & $1588,3 \pm 80,0$ & $\mathrm{~S}$ \\
3 & LANGDON/KU-20-8/AJARLY & $2,7 \pm 0,1$ & $1289,1 \pm 64,5$ & $\mathrm{MS}$ \\
6 & LANGDON/KU-20-8/FARABI & $2,7 \pm 0,2$ & $1322,8 \pm 65,1$ & $\mathrm{MR}$ \\
7 & LANGDON/KU-2075/AJARLY & $3,1 \pm 0,2$ & $1280,5 \pm 65,1$ & $\mathrm{MS}$ \\
8 & LANGDON/KU-2075/FARABI & $2,5 \pm 0,1$ & $1385,1 \pm 69,3$ & $\mathrm{R}$ \\
9 & LANGDON/KU-2092/FARABI & $3,0 \pm 0,1$ & $1201,1 \pm 54,2$ & $\mathrm{R}$ \\
10 & LANGDON/KU-2144/STEKLOVIDNAYA & $2,4 \pm 0,1$ & $785,9 \pm 39,2$ & $\mathrm{MR}$ \\
11 & LANGDON/KU-2100/NAZ & $2,4 \pm 0,1$ & $851,2 \pm 40,8$ & $\mathrm{R}$ \\
12 & LANGDON/AT 55/STEKLOVIDNAYA & $3,8 \pm 0,2$ & $1469 \pm 73,5$ & $\mathrm{R}$ \\
13 & LANGDON/PI 508262/STEKLOVINDAYA & $3,1 \pm 0,2$ & $1368,4 \pm 65,4$ & $\mathrm{R}$ \\
14 & LANGDON/PI 508262/ZHETISU & $3,4 \pm 0,2$ & $1309,4 \pm 65,5$ & $\mathrm{R}$ \\
22 & LANGDON/KU-2097/ZHETISU & $0,6 \pm 0,1$ & $1023,1 \pm 51,2$ & $\mathrm{MS}$ \\
33 & LANGDON/KU-2097/AJARLY & $0,5 \pm 0,1$ & $839,6 \pm 42,1$ & $\mathrm{R}$ \\
36 & LANGDON/KU-2144/NAZ & $1,5 \pm 0,1$ & $1486,7 \pm 74,3$ & $\mathrm{MR}$ \\
\hline
\end{tabular}

Table 2. The correlation dependence between spikes productivity componentsin artificial and in natural inflectional phone of spores of spores of Puccinia striiformis West

\begin{tabular}{lcc}
\hline \multirow{2}{*}{ Features } & $\begin{array}{c}\text { Indexes of correlation in different inoculation of spores } \\
\text { of spores of Puccinia striiformis West }\end{array}$ \\
\cline { 2 - 3 } & \multicolumn{2}{c}{$\begin{array}{c}\text { Seedlings, artificial } \\
\text { Adult plants, natural }\end{array}$} \\
\hline Length of spikes, sm & $0.5^{* *}$ & $0.2^{*}$ \\
Number of productive stems & $0.5^{* *}$ & $0.1^{*}$ \\
Solidity of spikes & $0.1^{*}$ & $0.1^{*}$ \\
Weight of spikes, gramm & $0.9^{* * *}$ & $0.2^{*}$ \\
Number of grain in one spike & $0.7^{* *}$ & $0.2^{*}$ \\
Weight of 1000 grain, gramm & $0.6^{* *}$ & $0.6^{* *}$ \\
Number of grain in one ear & $0.7^{* * *}$ & $0.1^{*}$ \\
\hline
\end{tabular}

* - low correlation, $* *$ - moderate correlation, ***- high correlation 
seedlings lines were resistant to stripe rust (table 1).

The studying of correlation dependence between spikes productivity components (length of spikes, number of productive stems, solidity of spikes, weight of spikes, number of grain in one spike, weight of 1000 grain, number of grain in one ear) in artificial and in natural inflectional phone of spores of spores of Puccinia striiformis West. We pointed that during first case on seedlings have been pointed previously moderate and high correlation between indexes of spikes productivity in comparative with case on adult plants with natural inoculations which showed low correlation (table 2).

\section{CONCLUSION}

Studying of inheritance resistance to stripe rust in adult plants the F1 generation in crosses of HSW and commercial cultivars of winter wheat showed that on the phone of moderate occurrence of stripe rust on standard cultivars , 79 $\%$ of hybrids have showed resistance to stripe rust.

The evaluation of synthetic wheat seedlings specific resistance showed that only $46 \%$ of the hybrids showed resistance to yellow rust. Thus, adult plants, and synthetic wheat seedlings have different specific resistance to disease.

The studying of correlation dependence between spikes productivity components on artificial and in natural inflectional phone of spores of Puccinia striiformis West. showed that during first case on seedlings have been pointed previously moderate and high correlation between indexes of spikes productivity in comparative with case on adult plants with natural inoculations which showed low correlation.

\section{REFERENCES}

1. M. Koishibayev. Diseases of Cereal Crops. Almaty. 2002; 367. (In Russian).
2. Sh.Rsaliev, M. Koishibayev, A.Morgounov, and D. Kolmer. The analysis of population of stem and leaf rusts in Kazakhstan. Int. Conference. Almaty. 2005; 67-272. (In Russian).

3. Y. Dutbayev, M. Koishibayev, and N.Sultanova. Yellow rust resistant genes for winter wheat breeding in Kazakhstan // Phytopathology. 2014; 104(11): 36-36.

4. FAO statistical yearbook. World food in agriculture. Rome, 2013; 289.

5. R.M. Caldwell. Breeding for general and/or specific plant disease resistance. Proc. 3rd Int. Wheat Genetics Symp / Eds K. W. Finley, K. W. Shepherd. Canberra, Australia: Aust. Acad. Sci. 1968; 263-272.

6. J. E. Parlevliet., Partial resistance of barley to leaf rust, Puccinia hordei. I. Effect of cultivar and development stage on latent period / Euphytica. 1975; 24: 21-27.

7. R.P. Singh. Genetics and Breeding for Durable Resistance to Leaf and Stripe Rusts of Wheat / «Increasing Wheat Production in Central Asia through Science and International cooperation» / Proc. 1st Central Asian Wheat Conf. Almaty, 2003; 127-132.

8. A.E. Chumakov. Rust problem of Cereal Crops. Plant Protection. 1968; 4: 219-221. (In Russian).

9. R.A. Mcintosh Pre-emptve breeding to control wheat rusts. Euphytica. 1992; 6: 103-113.

10. J.A. Kolmer. Genetics of resistance to wheat leaf rust. Annu. Rev. Phytopathol. 1996; 34: 435455.

11. E.D. Kovalenko, A.I. Zhemchuzhina, and N.N. Kryateva The genetical structure of population of agent of leaf rust. Immunogical methods for developing of resistant to diseases cultivars of cereal crops. 2000; 4: 14-15. (In Russian)

12. B.A. Dospechov Methods of field experiments. M.: Kolos, 1985; 351. (In Russian).

13. N.P. Goncharov, and P.L. Goncharov The bases of Plant Breeding. $2^{\text {nd }}$ Edition. Novosibirsk. 2009; 427. (In Russian).

14. B.A. Chasanov. Rust Diseases in Uzbekistan and methods of control. Tashkent. 2007; 94 (In Russian).

15. A.P. Roelfs, R.P. Singh, and A.A. Saari. Rust Diseases of wheat: Concepts of Disease Management. Mexico. CIMMYT, 1992; 81. 